\title{
THE ORGANIZATION OF MEDICAL EDUCATION IN ELISAVETGRAD REGION IN THE SECOND HALF OF THE XIX CENTURY
}

\author{
Olena Vasiutynska ${ }^{1}$ \\ ${ }^{I}$ graduate student of the Department of Pedagogy and Management of Education, Volodymyr Vynnychenko \\ Central Ukrainian State Pedagogical University, Kropyvnytskyi, Ukraine, e-mail: lenar@i.ua, ORCID: \\ https://orcid.org/0000-0002-3967-0269
}

\begin{abstract}
The article reveals the history of the origin and organization of educational institutions for the training of medical workers in Elisavetgrad region in the second half of the XIX century. It was found that the history of medical education was a prominent page in the history of Elisavetgrad region of the pre-revolutionary period. In medical schools, in particular in the Elisavetgrad Medical and Surgical School (1787-1797), which was one of the best medical institutions in the Russian Empire and the first higher medical school in the empire of the historical period, which used original approaches to the educational process, effectively solved educational problems. The aims of the article are to reveal the history of the origin and organization of educational institutions for the training of medical workers in Elisavetgrad region in the second half of the XIX century. The publication uses a historical-retrospective method, which allows a retrospective analysis of the history of Elisavetgrad Medical and Surgical School in the study period and highlights its contribution to the development of medical education in the region. Historiographical review of the problem revealed that there are currently no scientific studies that would systematically and fully analyze the historiography of medical education in Elisavetgrad in the period under study, so the development of medical education in the second half of the nineteenth century needs further study. Analysis and systematization of research on this issue has further development. The accumulated experience of regional medical education in the outlined historical period can be useful at the stage of revival and development of medical education in Ukraine.
\end{abstract}

Keywords: medical education, Elisavetgrad region, medical educational institutions, Elisavetgrad medical-surgical school.

JEL Classification: JEL I0; I20

Formulas: 0; fig.: 0; tabl.: 0; bibl.: 8

Introduction. The modern formation of medical education requires the study of the historical experience of its implementation in different regions of Ukraine, including period of the second half of the XIX century. The study of the history of regional education provides an opportunity to study the existing historical experience of medical education, to predict the main trends of its development in the future, the study of such development in this period will enrich modern science with knowledge about the mechanisms of modernization of medical education.

The relevance of the chosen topic is enhanced by the presence of contradictions between the experience of medical education in Elisavetgrad region in the historical period and the insufficient level of its scientific understanding, generalization and systematization for creative use in modern conditions.

Literature review. During the present period, the interest of scientists in the system of medical education and in the peculiarities of the development of certain medical schools in Ukraine in the second half of the XIX century has significantly increased, as evidenced by the works of modern scientists S. Verkhratsky [2], O. Golyachenko [3], M Kushik [4], V. Pliushch [7] and others. Researchers are trying to assess more objectively the achievements in the field of medical education, due to the 
openness of archives and the availability of new sources. It is obvious that the current level of development of the methodology of historical and pedagogical sciences has allowed modern researchers to more fully and qualitatively present the experience gained over a period of time.

However, the genesis of medical education in Elisavetgrad region of the studied period is represented by a small number of scientific investigations of $\mathrm{V}$. Bosko [1], P. Sydorenko [8], S. Prysyazhniuk [8]. The holistic history of the development of medical education in the region of the second half of the XIX century has not yet been properly covered in historiography.

Aims. The aims of the article are to reveal the history of the origin and organization of educational institutions for the training of medical workers in Elisavetgrad region in the second half of the XIX century.

Methods. The publication uses a historical-retrospective method, which allows a retrospective analysis of the history of Elisavetgrad Medical and Surgical School in the study period and highlights its contribution to the development of medical education in the region.

Results. The development of medical education in Elisavetgrad region in the second half of the XIX century was determined by various regional factors, which were also based on national educational reforms, the need to train qualified medical workers and others. The development of the educational medical sphere in Elisavetgrad region took place almost simultaneously with the relentless and rapid development of the region after the founding of the fortress of St. Elizabeth.

The growth of the army, the increase in the urban population, industrial workers, and the general epidemic distress in the country required adequate medical care, including for trained workers. Hospitals are becoming centers where doctors and paramedics are trained. In fact, these institutions in essence were the first higher medical schools in Russia at that time. The hospitals at which they were opened were called general.

As a result of the school reform of 1864, a unified system of primary education was introduced in the Russian Empire, the management of public schools was transferred to county and provincial school councils, and the maintenance of educational institutions became the responsibility of the local population and zemstvo. However, these changes were not rapid, as they were determined primarily by social-economic conditions and autocratic policy in the field of education, and the proclaimed idea of universal education did not change in practice the class nature of education. The reforms of the 60's and 70's intensified the process of development and expansion of educational institutions network in the territory of the Russian Empire [6, p. 54]. The year 1861 became fateful for the Russian Empire in general, and for Ukraine in its composition in particular. It is the starting point in the development of Elisavetgrad: in 1861 the city was transferred to the civil department, and soon (1865) was restored to the status of a county center.

Note that in Elisavetgrad district of Kherson province the first hospital was founded in 1777, the first doctor of the battalion D. Vovchanetskyi named it in honor 
of St. Elizabeth. The hospital was designed for 200 beds. Later, a large Elisavetgrad hospital was established here.

The events of the Russian-Turkish War of 1877-1878 led to the establishment of medical courses in the city, as a hospital for wounded soldiers was located in Elisavetgrad, which was cared for by the famous surgeon and organizer of education M. Pirogov. The leaders of the Elisavetgrad branch of the Red Cross Society opened courses for sister of charity at the hospital in zemstvo, where practical classes were conducted by local and military doctors. Graduates of such classes helped medical workers in military hospitals, infirmary, sanitary units [9].

In 1788-1797, one of the first medical schools in Ukraine, the Medical and Surgical School, existed in Elisavetgrad. During the whole period of its existence, 247 students and 10 volunteers studied here. V. Dominicius taught chemistry, physics and medical practice for the first five years, and O. Zviryakov taught chemistry, botany, pathology and therapy for the last two years; anatomist E. Mukhin and surgeon D. Volchanetsky also worked in it [5, p. 84], during the Crimean War (18531856), M. Pirogov, a prominent scientist and the founder of military field surgery, worked for some time in the military infirmary near the fortress [5, p. 84]. In fact, it was the first higher medical education in the Russian Empire at that time.

By the order of G. Potemkin as the inspector of the hospital and schools was appointed V. Shariy, and he managed the school before its closure. The inspector was respected among the residents of Elisavetgrad because he allowed to dispense prescription drugs from a hospital pharmacy and to consult patients.

Initially, the Elisavetgrad Medical and Surgical School was headed directly by G. Potemkin, after his death by General M. Kakhovsky, and from 1793 by O. Suvorov. It should be noted that both G. Potemkin and O. Suvorov were very interested in the creation of this school, because it was to train doctors for the army on the Russian-Turkish front. The Ukrainian community, for its part, was also interested in the development of this school, because, firstly, it was a long-standing dream of the Ukrainian elite to have their own higher education institution in Ukraine, and secondly, young people were more enthusiastic about studying in Elisavetgrad than to distant and foreign St. Petersburg and Moscow.

All students of the school were mostly from Ukraine, including students of Kyiv-Mohyla Academy, Kharkiv, Chernihiv and Pereyaslav schools and Ekaterinoslav, Belgorod and Uman seminaries. According to their social composition, the students were mostly children of doctors, clergy, Cossacks and small gentry. Ethnicity was dominated by Ukrainians, but there were also Russians, Poles, and Moldovans. Students lived in private apartments or settlements Kovalivka, Bykiv and Zamlynkivsk. The largest enrollment took place in 1791, when 47 students were enrolled, and in 1794, when 84 students were admitted (for example, no more than 20 students were admitted to Moscow and St. Petersburg medical and surgical schools annually).

Elisavetgrad Medical and Surgical School was organized on the model of other medical institutions in the Russian Empire. The main requirement for entering school was knowledge of Latin, which at that time was the international language of science. 
In accordance with the general provisions of the hospital, from 1735 a period of study from 5 to 10 years was established in hospital schools. By order of the Medical Office of July 4, 1754, seven years of study were established equally for all schools. But usually this time was not observed. All students who study well, after two or three years of study and exam as a future doctor, received the title of doctor, and after one or two years - the title of doctor. Even later, in 1795, every student who studied for three years and passed the exam, received the title of paramedic, after the fourth year of training candidate of surgery [8, p. 54].

The first three courses taught the following subjects: Mathematics, Physics, Chemistry, Botany, Anatomy, Physiology, Medical material, Formulation, Pathology, Therapy, Surgery and sectional course. In the fourth year only Surgery and Obstetrics were studied deeply.

The fifth year of study was devoted to patient care, rotation in the so-called clinical departments and practical exercises. At the same time, students need to perform at least four basic operations on the body and prepare at least two anatomical preparations.

It should be noted that the anatomy studied not only from textbooks and atlases, as often happened in foreign universities, but also must guide the section of dead or killed. Each hospital organized anatomical museums and worked as a so-called master drawing that had redraw the nature of anatomical preparations. In addition to general anatomy students studied also pathological anatomy. This was created by a section of deaths in the hospital, which in turn significantly improves the diagnosis of diseases. From this point of view an interesting thing is a guide for physician hospitals, dated 1753. Overall, during the existence of school teachers and students were conducted 550 autopsies, and that given the fact that in those days in Europe never performed such a procedure.

Along with students studied anatomy principles of forensic medicine and physiology taught anatomy, or simultaneously with, or as a separate discipline. Detailed attention to the study of so-called Materia Medica, of course, which included: Botany, Pharmacology, Pharmacognosy and Formation. It is important that this subject is taught not only in theory but also practical exercises conducted in hospital pharmacy and botanical garden.

Special attention was paid to the study of Surgery and Desmurgy. Surgery was studied primarily on the carcasses, whereby each student had to make a number of operations. There was the obligatory presence with operations and participate in rounds of patients. Desmurgy students studied first at phantoms, and made dressings for patients. Interestingly, the Ukrainian doctors, scientists and J. N. KarpynskyySapolovych were some of the best sets of operational work. Obstetrics studied both phantoms and practical exercises. Other clinical disciplines, such as eye, leather, mental and nervous diseases, taught not only in theory, as was common in most foreign universities, but also directly studied in patients as the hospital had a large clinical database. Of course, much attention was paid also to the study of internal medicine of person. From 1735, according to the "General Regulations on Hospitals", staffs were created, which included the positions of chief physician, junior or so- 
called lecture physician and a number of physicians. In addition to the head teacher and the junior doctor, there were also doctors and operators. Students had to listen to lectures of various clinical disciplines, conduct exercises, record medical history.

In particular, in Elisavetgrad Medical and Surgical School both theoretical and practical research was conducted very quickly. Each day, students listened to seven hours of lectures and worked at the patient's bedside for four hours. Theoretical research, according to archival materials, was conducted according to the following schedule: from 10 to 12 hours of acquaintance with diseases, in the afternoon from 2 to 4 hours - treatment with drugs, from 7 to about 10 hours of anatomy and surgery. Also during training regularly tested students' knowledge. For example, there were tests weekly, monthly, three-month and year-end was held so-called final general exam. In general exams members of the Medical Board, divisional doctors, and other distinguished guests often attended. At the annual general exam all doctors and doctors working in the hospital attended, and each of the participants could ask the student who passed an examination [8, p. 65].

Students of Elisavetgrad medical-surgical school as students of other medical and surgical schools of Empire, used textbooks in Latin, German and Russian. Interestingly, most medical textbooks have been translated into Russian or Latin by Ukrainian scientists and physicians. Thus, the Ukrainian scientist N. Karpynskyy was the first in the Empire who composed the pharmacopoeia (1778), and $\mathrm{N}$. Maksimovic-Ambodik composed medical Latin-Russian dictionary, medical and surgical pathological dictionary, six-language textbook on obstetrics and 4-part book "Doctor's materials."

The first teachers of Elisavetgrad Medical and surgical schools were: Senior hospital doctor P. Kolb, who received education in the Moscow Hospital School and was a teacher in Petersburg hospital. In 1789 he received his medical degree and taught anatomy, physiology, surgery and so-called " Doctor's materials", as he wrote in his letter addressed to the Chief Medical College A. Vasilyeva. Mr. Kolb was a teacher at the school from 1789 till the day of its liquidation. Dr. V.Dominitsiyus taught Medicine - a course that included: pharmacognosy, pharmacology, pharmacy, and later botany and medical practice. He worked since the organization of the school till 1793, then he was transferred to the Black Sea Fleet. Then Dr. I.Kerner continued teaching and gave up teaching due to illness. Suvorov then turned to the medical board to send a teacher, and Dr. Ostap Zviryaka was appointed to this place, which began work in July 1794, and taught chemistry, medical practice.

Graduates Elisavetgrad medical-surgical school initially received appointment to the army units that were deployed in southern Ukraine and the Black Sea Fleet. Subsequently destination geography graduates increased. They worked in Belarus, the Baltic States, in Kamchatka.

The school was famous for its graduates, among whom the most famous E. Mukhin, O. Zviryaka, D. Volchanetsky, S. Nemirov and A. Chorba, A. Bystroglazov, because they all belonged to prominent Ukrainian doctors and contributed not only to the development of Elisavetgrad medical and surgical school, but also to Ukrainian medicine in general [1, p. 57]. 
Elisavetgrad Medical and Surgical School existed for 10 years, from the beginning of 1787 to the middle of 1797 . The school had 247 students and 10 volunteers. Thus, future doctors and 153 doctors learned at the school. During the XVIII century 2000 doctors were educated in the empire. So we can say that every eighth state doctor was educated at the Elisavetgrad Medical and Surgical School. At the time of closing, 95 students and 9 volunteers were enrolled who wanted to take future exams for doctors. Thus, there was no question about the lack of people willing to study there. But the war ended, and the central government of the Russian Empire was not interested in maintaining higher medical education in Ukraine. In a report addressed to the Medical Board, school inspector P. Sharoy clearly demonstrated the need for the continued existence of the school. But, despite the existence of a successful institution for 10 years, these facts do not convince the central government and Paul I adopted a report on the liquidation of the institution on June 13, 1797. Students were sent to the Moscow and St. Petersburg Medical and Surgical Schools [8, p. 70].

Discussion. Thus, the history of medical education was a significant page in the history of Elisavetgrad region of the pre-revolutionary period. In medical schools, in particular in the Elisavetgrad Medical and Surgical School (1787-1797), which was one of the best medical institutions in the Russian Empire and the first higher medical school in the empire of the historical period, which used original approaches to the educational process, effectively solved educational problems.

Conclusions. The historiographical review of the researched problem allowed to establish that currently there are no such scientific researches where the historiography of development of medical education of Elisavetgrad region of the studied period would be systematically and fully analyzed, therefore the question of development of medical education of the region in the second half of the XIX century needs further study.

The accumulated experience of regional medical education in the outlined historical period can be useful at the stage of revival and development of medical education in Ukraine.

\section{References:}

1. Bos'ko, V. M. (2004), Vyznachni postati Stepovoyi Ellady: do 250-richchya zasnuvannya fortetsi Svyatoyi Yelyzavety, mista Yelysavethrada ta 65-richchya utvorennya Kirovohrads'koyi oblasti [Prominent figures of Steppe Greece: to the 250th anniversary of the founding of the fortress of St. Elizabeth, the city of Elisavetgrad and the 65th anniversary of Kirovograd region], Kirovograd: Informatsiyna merezha, CH. 1, $376 \mathrm{~s}$.

2. Verkhrat·s'kyy, S. A. (1991), Istoriya medytsyny [History of Medicine], K. : Vyshcha shkola, $431 \mathrm{~s}$.

3. Holyachenko, O. (20016), Istoriya medytsyny [History of medicine]: posib. 2-he vyd., dopovn. Ternopil' : TDMU, $326 \mathrm{~s}$

4. Kushyk, M. L. Orhanizatsiya medychnoyi osvity v Ukrayini v druhiy polovyni XIX - pochatku XX st. [Organization of medical education in Ukraine in the second half of the XIX - early XX centuries], [Elektronnyy resurs], Rezhym dostupu: http://www. rusnauka.com/26_SSN_2008/Pedagogica/34933.doc.htm.

5. Istoriya mist i sil Ukrayins'koyi RSR. Kirovohrads'ka oblast', (1972) [History of towns and villages of the Ukrainian SSR Kirovograd region], Kyiv, T. 8, 1972, 816 s.

6. Lipnik, V. (2003), Shkol'nyye reformy v Rossii. Kharakteristika reform shkoly v dorevolyutsionnoy Rossii, School reforms in Russia [Characteristics of school reforms in prerevolutionary Russia], Obrazovaniye, №4, S. $46-54$. 
7. Plyushch, V. (1970), Narysy z istoriyi ukrayins'koyi medychnoyi nauky ta osvity [Essays on the history of Ukrainian medical science and education], Myunkhen, $540 \mathrm{~s}$.

8. Sydorenko P. I., Prysyazhnyuk S. S. (2008), Medychna osvita Kirovohradshchyny: storinky istoriyi [Medical education of Kirovograd region: pages of history], Kirovograd : Ymeks LTD, 158 s.

Received: September 16, 2020

Approved: October 14, 2020 